\title{
Caminhos cruzados: os ambientalistas e o Poder Público no Vale do Rio dos Sinos - RS
}

Fabiano Quadros Rückert ${ }^{1}$

Memórias de Educação Ambiental no Vale dos Sinos - RS

O processo de formação do ambientalismo apresentou variaçóes nacionais e regionais no ritmo do seu desenvolvimento e incorporou demandas procedentes de diferentes grupos sociais, portanto, seria um grande equívoco pensá-lo de forma homogênea e cristalizada. Dentre os diversos fatores que contribuíram para a pluralidade de ideias e práticas sociais acionadas pelo ambientalismo, cabe ressaltar aqui a participaçáo de segmentos da sociedade civil na discussão dos problemas ambientais contemporâneos e na proposição e execução de iniciativas para combatê-los.

Parte da história do ambientalismo foi registrada em documentos (atas de reunióes, cartas, panfletos, abaixo-assinados etc.) produzidos pelos ambientalistas no decorrer de seus trabalhos. Algumas atividades foram registradas pela imprensa e outras podem ser estudadas nos próprios textos do Poder Público; açóes judiciais e projetos de leis, por exemplo, são duas fontes documentais que contêm vestígios da atuação dos ambientalistas. $\mathrm{O}$ volume de documentos disponíveis para a pesquisa histórica é grande, e apesar do surgimento de estudos direcionados ao assunto, ainda se sabe pouco sobre as ideias e estratégias de mobilização dos ambientalistas. Diante de um saber histórico incipiente sobre esse tema, a História Oral pode oferecer uma importante contribuição, não para complementar ou contrapor outras

1 Doutorando em História pelo PPGH da Unisinos. 
fontes documentais, mas, sim, para produzir a ressignificação do passado, que é uma das principais consequências da experiência de recordar e de falar sobre recordaçóes.

Feitas essas consideraçóes introdutórias, proponho apresentar alguns resultados de um trabalho de História Oral realizado com ambientalistas do Vale do Rio dos Sinos no Rio Grande do Sul. A maior parte das entrevistas foi realizada em 2006, na fase final da dissertação de mestrado e, recentemente, em 2011, foram realizadas duas novas entrevistas, compondo um banco de dados com memórias de 18 ambientalistas da região. É a partir das informaçóes produzidas no decorrer dessa experiência de aplicação da História Oral que pretendo analisar elementos destacados nas recordaçóes de ambientalistas do Vale dos Sinos. Os dois temas mais recorrentes entre os entrevistados foram as práticas de Educação Ambiental e as relaçóes com o Poder Público. A percepção da recorrência desses temas surgiu como consequência da pesquisa e, portanto, ela expressa as marcas de um trabalho historiográfico de fragmentação, recomposição e comparação entre as recordaçóes registradas no decorrer do uso da História Oral. Essa observaçáo, apesar de simples, é importante para mantermos a distinção entre as recordaçóes narradas e o texto historiográfico criado a partir delas.

Na pesquisa de História Oral realizada com ambientalistas do Vale dos Sinos, o ponto de referência projetado pela memória dos entrevistados para o surgimento da Educação Ambiental foi Henrique Luiz Roessler (1896-1963), considerado um dos pioneiros do ambientalismo no Brasil. Roessler nasceu e viveu no município de São Leopoldo, onde criou, em 1955, a União Protetora da Natureza (UPN). Através dessa entidade, buscou intensificar o trabalho de preservação ambiental que realizava, produzindo e distribuindo textos e desenhos educativos e fiscalizando a caça, a pesca e o desmatamento ilegal no Rio Grande do Sul. Uma parte do seu trabalho em defesa da natureza pode ser conhecida através dos textos e desenhos que ele produziu no período entre 1953 e 1963. Quando estudei a produção textual de Roessler, percebi a necessidade de saber quais os efeitos que o seu pensamento e as suas açóes provocaram na sociedade da época, sendo que essa necessidade levou-me ao encontro de Kurt Schmeling e Ernest Sarlet - dois ambientalistas que foram amigos de Roessler e que compartilharam dos seus ideais.

Kurt Schmeling hoje é professor aposentado, e durante os anos 70 participou da inclusão da disciplina de Ecologia no currículo da Fundação 
Evangélica de Novo Hamburgo - instituição de ensino pela qual passaram alguns líderes do movimento ambientalista no Vale dos Sinos. Quando perguntei ao professor Schmeling como foi o começo da sua formação como ambientalista, essa foi a sua resposta:

Bom, aí eu tenho que recuar muitos anos. No tempo que eu era aluno do Ginásio Sinodal, naquele tempo lá em São Leopoldo, sempre me chamou a atenção uma pequena vitrine de uma lojinha ao lado da Igreja Católica de São Leopoldo. Só mais tarde eu fiquei sabendo que a lojinha era do Roessler, mas, naquela vitrine, então, tinha exposiçóes sobre a natureza, as aves, as árvores aqui da nossa regiáo e alguns apelos. Só mais tarde eu fiquei sabendo quem era Henrique Luiz Roessler, mas, como aluno, isso já me marcou, e talvez, então, através dessa modesta vitrine em São Leopoldo, surgiu a minha abertura para a natureza e a preservação da natureza.

O convívio entre esses dois personagens possibilitou a criação de uma rede de ensinamentos que contribuiu para o desenvolvimento da conscientização ambiental no Vale dos Sinos. Schmeling levou para suas aulas, na Fundação Evangélica, textos que Roessler publicou no jornal Correio do Povo entre 1957 e 1963, e buscou estimular a postura crítica dos alunos diante dos problemas ambientais. Ele também oferecia aos seus estudantes a leitura de Albert Schweitzer - um dos autores considerados pioneiros na discussão filosófica da ética ambiental. Apostando na continuidade e no fortalecimento da Educação Ambiental, Schmeling e um grupo de alunos da Fundação Evangélica criaram, em 1978, o Movimento Roessler pela Preservação Ambiental - entidade que continua existindo e que desde o seu surgimento exerce um papel relevante no ambientalismo da região.

Assim como Schmeling, Ernest Sarlet também trabalhou como professor e diretor na Fundação Evangélica de Novo Hamburgo, e desde os anos 50 desenvolveu trabalhos no campo da Educação Ambiental. Imigrante belga, graduado em Filosofia, Sarlet encontrou na obra de Albert Schweitzer o convite para uma ética ambiental e, no convívio com Roessler e Schmeling, encontrou inspiração e exemplos práticos dessa ética.

Nos anos 80, Sarlet coordenou a Secretaria de Educação, Cultura e Desporto de Novo Hamburgo, e através desse órgão do Poder Público implantou um importante trabalho de Educação Ambiental, criando então o Horto Municipal e incentivando a produção de material educativo sobre a 
fauna e a flora do Vale dos Sinos. Na ocasião em que a entrevista foi realizada, ele estava com a saúde fragilizada e, apesar das dificuldades respiratórias, sentiu-se feliz em recordar seu passado como educador e ambientalista. Cabe salientar que Ernest Sarlet morreu dois meses depois de conceder a entrevista. E, diante da sua disposição para contribuir com a pesquisa, fica o reconhecimento de que a memória, mais do que um campo de estudos, é o ponto de encontro do ser humano com a própria finitude e também o palco da sua luta contra o esquecimento. O trabalho que Ernest Sarlet ajudou a desenvolver na Prefeitura de Novo Hamburgo faz parte de um conjunto mais amplo e diversificado de experiências com Educação Ambiental registradas no decorrer da pesquisa, e deve ser pensado como parte da construçáo do ambientalismo no Rio Grande do Sul e no Brasil.

Um dos aspectos destacados pelos entrevistados foi a carência de material didático referente às questôes ambientais. No começo dos anos 70, quando a caracterização da crise ambiental contemporânea estava na sua fase inicial, os textos de Henrique Luiz Roessler e de Balduíno Rambo - autor do livro A Fisionomia do Rio Grande do Sul - foram obras de referência na formação de vários ambientalistas no estado. Percebemos um registro dessa importância nas recordações do biólogo Renato Petry Leal sobre as condições iniciais de estudo das questóes ambientais:

(...) mesmo dentro da História Natural que é hoje o curso de Biologia, tu náo tinha uma conscientizaçáo grande em favor da natureza, (...) mas a gente já estava a par de várias atrocidades que vinham ocorrendo em relação ao meio ambiente (...).

(...) o que existia escrito e era bastante coisa escrita, eram as crônicas do Roessler e a gente tinha acesso às publicaçóes que ele tinha feito no Correio do Povo, principalmente. Então, ali havia um material muito bom, muito interessante, e várias delas foram publicadas depois como livro básico, principalmente sobre o Rio Grande do Sul (...). O outro era o livro do Balduíno Rambo, "A fisionomia do Rio Grande do Sul", inclusive o Carneiro descobriu na gráfica uma porção daquele livro que estava atirada num canto (...) e ele levou aqueles livros e estava vendendo muito barato (...). Mas era basicamente isso o que tinha naquela época, eu não me recordo de outra coisa que enfocasse as necessidades de conservaçáo do meio ambiente. 
As palavras de Renato Petry Leal nos remetem a dois autores fundamentais para a formação intelectual dos ambientalistas gaúchos e também destacam o nome de Augusto Carneiro, um dos personagens mais conhecidos do movimento ambientalista no Rio Grande do Sul. Em 1971, Carneiro foi um dos fundadores da Agapan (Associação Gaúcha de Proteção ao Ambiente Natural) e usou a sua rede de contatos com escritores e editoras para incentivar a publicação e circulação de textos sobre as questóes ambientais no Brasil e no exterior.

A carência de uma bibliografia mais aprofundada e a percepção de que mesmo no ensino superior a abordagem dos problemas ambientais era muito precária no começo dos anos 70 aparece também nas recordaçóes do professor aposentado Werner Ziegler. Em 1969, Ziegler ingressou na antiga Faculdade de Filosofia, Ciências e Letras Cristo Rei, que depois passou a fazer parte da Universidade do Vale do Rio dos Sinos (Unisinos). Nessa instituição, ele cursou Licenciatura Plena em História Natural e uma parte da formação acadêmica que recebeu foi relembrada durante a sua entrevista:

(...) eu lia as crônicas do próprio Roessler, que sempre me interessaram (...), ele foi um precursor nessa questão ambiental (...). É que, na realidade, eu posso te dizer que não havia uma literatura assim muito ampla disponível na época (...), a gente se informava dessas questóes através da imprensa com assuntos de reportagens e tinha as crônicas do Roessler que você podia ler.

A minha formação dentro da área de Ciências foi mais técnica: pesquisar, tratar assuntos de Biologia, Zoologia, Botânica, coisas especificamente nestes campos, e não nessa amplitude que a Ecologia possibilita onde é tudo interligado. Então, quando eu me formei, a Ecologia era uma coisa tratada assim como um apêndice, (...) a própria bibliografia que era oferecida, ela era bem fraquinha.

Diante da carência de bibliografia sobre os problemas ambientais enfatizada nas recordaçóes dos entrevistados e da valorização dos poucos textos acessíveis na época, podemos inferir que o desenvolvimento da Educação Ambiental no Rio Grande do Sul dos anos 70 superou as adversidades e produziu um saldo positivo. Na década seguinte, o movimento ambientalista do Vale dos Sinos apresentou um expressivo crescimento no número de entidades e colaboradores e retomou a prática adotada por Luiz 
Henrique Roessler de produzir e distribuir o seu próprio material educativo. Igualmente importante para a concretizaçáo desse crescimento, foi a continuidade do trabalho ambientalista de apresentar o Rio dos Sinos e os seus problemas ambientais à comunidade - fato destacado nas recordações do agrônomo Luís Marcelo Tisian a respeito do trabalho educativo que a União Protetora do Ambiente Natural (UPAN) promoveu no final da década de 80 e começo de 90 :

O que nós fazíamos na época e que ajudou muito eram palestras em escolas e associaçôes de bairro. Eu, junto com o Márcio Linck, acho que fomos as pessoas que mais deram palestras em toda a regiáo do Vale dos Sinos. Eu acredito que nós dois demos palestras para mais de 5 ou 6 mil alunos no período em que a gente fez essa atividade (...). Basicamente a nossa ação em escolas era essa: as pessoas nos contatavam, marcavam um horário, íamos lá com o projetor de slides, ainda naquela época não tinha Data Show e PowerPoint, então íamos com o projetor de slides e nós tínhamos uma sequência de mais ou menos 50/60 slides mostrando toda a calha do Rio dos Sinos, da sua nascente até o delta, mostrando ali as diferentes situaçóes em que ele se encontrava, quais eram os problemas e eventualmente algumas soluçôes.

Da recordação de Tisian, cabe destacar a existência de redes de contatos entre as escolas e a UPAN, que possibilitavam a realização das palestras e exposiçôes de imagens sobre o ambiente da regiáo e, consequentemente, fomentavam práticas de Educação Ambiental.

O trabalho de interação entre ambientalistas e escolas públicas e privadas da regiáo havia sido iniciado por Henrique Luiz Roessler e fomentado pelas ONGs criadas no decorrer dos anos 70, 80 e 90 . O trabalho era essencialmente educativo, mas as suas intençóes e estratégias excediam os procedimentos e espaços tradicionais da educaçáo escolar: as açôes de Educação Ambiental buscavam provocar mudanças nos hábitos e nos valores da sociedade. E foi essa intencionalidade de mudança que Maria Olisa - professora de Ciências da Rede Municipal de Novo Hamburgo - enfatizou quando recordou suas atividades na Associação Ecológica Terraguar:

(...) a atitude que a gente acreditava que seria forte era dar o exemplo. Então, várias vezes a gente se armou de bota, de luvas, de sacos de lixo e 
fomos para dentro do arroio retirar o lixo que estava dentro do arroio, foram os famosos mutiróes. Foi um bom exemplo. Nós queríamos que fosse um exemplo e foi. Então, assim começou a surgir mutirão em tudo que era canto, e a gente ficou bem contente com isso. (...) a gente conseguiu retirar de dentro do arroio toneladas de lixo, fazia montes de lixo, esculturas de lixo, de tanto que saía. E isso envolvia a comunidade, de dez que passavam dois se engajavam no processo, perguntavam o que a gente estava fazendo ali; de repente achavam interessante e aderiam e ficavam ali ajudando.

A satisfação dos ambientalistas, tanto para os da geração inicial quanto para os que ingressaram na luta no decorrer da década de 80 , náo consistia em apresentar à sociedade o quadro de poluição do Rio dos Sinos, do Arroio Pampa ou de outro dos seus afluentes, mas em ajudar no conhecimento dos ecossistemas locais, incentivando o respeito e a atenção para com a natureza da região. Nessa perspectiva, o trabalho de apresentação dos problemas ambientais para a comunidade local pode ser pensado como uma experiência educativa de ressignificação da paisagem urbana e de conscientização da responsabilidade humana diante da degradação da natureza.

Cientes de que o fortalecimento do ambientalismo implicava a discussão pública dos problemas ambientais, os ambientalistas também usaram a escrita para impulsionar essa discussão e, nessa tarefa, o agrônomo Arno Kayser alcançou um expressivo sucesso. $\mathrm{Na}$ entrevista que concedeu fez uma referência ao seu envolvimento com a produção de textos ambientalistas:

(...) eu sempre trabalhei muito essa questão de escrever (...). Essas coisas assim de escrever artigos sobre o meio ambiente e produzir material sobre o meio ambiente eu acho uma coisa bastante importante, porque a gente carece (...), a gente tem muito livro técnico sobre botânica, fauna, flora e coisa e tal, mas não é voltado para a perspectiva local e numa linguagem adaptada para as pessoas que têm pouco conhecimento botânico ou pouco conhecimento científico, é esse o objetivo, e eu acho uma coisa bastante importante. As pessoas que têm formação científica não se dão conta de que não tem mais gente do lado delas, porque elas náo conseguem se comunicar com um monte de gente que gosta das mesmas coisas que eles, que gosta de bichos, que gosta de plantas, que gosta de morros e de mato, porque elas criaram uma linguagem muito sofisticada e, pior, a linguagem científica, além de ser sofisticada é em latim, um resquício da 
cultura greco-romana, e ainda de 5 em 5 anos muda tudo (...). Qual é o nome dessa árvore? Como se planta? Quando? Quando ela floresce? São perguntas que muitas pessoas fazem e elas não têm, ou não sabem achar num livro produzido para nível nacional ou internacional; a espécie que é ali da esquina, que está plantada na esquina. E, às vezes, a gente tem na arborização urbana muitas espécies exóticas para as pessoas saberem de que país que ela é, de que região que ela é, de que clima que ela é. E isso inclusive ajuda as pessoas a entender (às vezes) porque ela está bem, se está bem plantada ou mal plantada, se está doente ou não está doente, todas essas coisas. Então é esse o objetivo e com essa mobilização se criou toda uma expectativa nas crianças de receber um prêmio por aquele trabalho que foi realizado (...).

No conjunto, as experiências de Educação Ambiental pesquisadas demonstram que, na concepçáo dos entrevistados, o caminho para as mudanças desejadas pelo movimento ambientalista iniciava pelo reconhecimento da existência dos problemas ambientais, passava pela busca do entendimento desses problemas e almejava a construção de soluçóes coletivas, ou seja, de soluçôes que contassem com o interesse e o envolvimento de toda a comunidade. Essa leitura das pretensóes do movimento ambientalista abre caminho para tratarmos do segundo eixo temático proposto para este texto.

\section{Memórias da politização do ambientalismo no Vale dos Sinos}

O conceito de politizaçâo do ambientalismo foi usado em minha dissertação de mestrado para analisar o surgimento e a discussão de demandas sociais voltadas à preservação ambiental e à transformação dessas demandas em leis e açóes governamentais. Na segunda parte do artigo, proponho pensarmos essa politização a partir de um conjunto de recordaçóes que abordam as relaçóes do movimento ambientalista do Vale dos Sinos com o Poder Público e acredito que, por meio delas, é possível recompor um quadro de experiências de cooperação ou de conflitos entre demandas ambientalistas e práticas de governo. Existe também a intenção de abordar parcialmente a institucionalização dos assuntos ambientais na região, mediante a criação 
de leis e órgãos governamentais e a observação de mudanças nos serviços públicos referentes ao meio ambiente.

Como as relaçóes entre os ambientalistas e o Poder Público podem ser pensadas na ótica da História Oral? Para responder a essa questão, considero oportuno recorrer à entrevista realizada com Augusto Carneiro da Cunha, pertencente à primeira da série que formou o conjunto da pesquisa. Quando iniciei a entrevista com Carneiro, pretendia seguir um roteiro de perguntas sobre datas, nomes e fatos referentes ao ambientalismo no Brasil e no Rio Grande do Sul, mas, para minha surpresa, encontrei uma narrativa de memórias pré-construída pelo entrevistado e optei por privilegiar suas recordações em detrimento das minhas curiosidades. Inicialmente, estranhei o resultado da entrevista e tive a sensação de que havia falhado na aplicação do método, porém, no decorrer da transcriçáo e da leitura de suas memórias, encontrei importantes recordaçóes sobre as relaçóes do governo com os ambientalistas, dentre as quais destaco a seguinte:

Então nós fundamos o movimento ecológico na década de 60 e 70, (...) e agora as contribuiçóes deste movimento: em primeiro lugar nós temos a legislação. A legislação que contém a destruição e que dá mais fôlego à vida humana nesse planeta por causa das contençóes parciais, e ela é iniciativa nossa.

Em outros lugares nós trouxemos para o movimento ecológico a questão do lixo. Bom, havia no Brasil, para prefeituras que aceitassem o tratamento parcial do lixo, a orientação do chamado aterro sanitário: não havia reciclagem, era só tapar. Os aterros sanitários tenderiam - pelo volume e a não reciclagem - a se esgotar com o tempo. (...), e aí surge a ideia, só a ideia e não a prática, do ecologismo com a reciclagem e uma série de providências no setor do lixo.

Na interpretação de Carneiro, a combinação da legislação com a reciclagem do lixo impediu as previsóes catastróficas divulgadas nos anos 70, mas no decorrer do processo histórico, a participação dos ambientalistas foi diminuída e até "omitida" pelo governo. O tratamento dispensado pelo governo aos ambientalistas, na opinião do entrevistado, estaria associado a sua capacidade de contratar técnicos e de criar repartiçóes responsáveis pela área ambiental, mas os "defeitos no caráter" dos políticos também explicariam esse tratamento: 
Eles [os políticos] contrataram técnicos e existem repartições para tratar da questão natural, seja no lixo, seja na agricultura, seja nos parques, eles têm seus técnicos, são pretensiosos e não reconhecem; historicamente, eles não reconhecem. E eu acho que tão cedo não vão reconhecer, a tendência dos políticos é roubar, se acomodar, empregar parentes, essa tendência não foi modificada.

O que Carneiro abordou no ritmo da memória e na lógica da sua própria narrativa é um tema complexo e que diz respeito à institucionalização das questóes ambientais e ao processo de controle governamental da agenda política ambiental (controle construído gradualmente via legislação, discursos, estudos, normas e procedimentos técnicos gerados no âmbito do Poder Público). Segundo a interpretação proposta por Agripa Farina Alexandre (2000), esse processo, contra o qual Carneiro protestou, contribuiu para a perda da radicalidade do movimento ambientalista brasileiro. Náo cabe aqui discutir a validade da interpretação de Alexandre, uma vez que ela é pautada em argumentos coerentes levantados pelo autor. O que importa, nesse caso, é reconhecermos a necessidade do trabalho historiográfico de dialogar com as discussóes ambientais fomentadas por outras áreas, como as Ciências Políticas, a Sociologia e a própria Educaçáo Ambiental, explorando esse diálogo para ampliar as possibilidades de compreensão da historicidade das questóes abordadas pela História Ambiental.

Vejamos como a institucionalização das questôes ambientais ocorreu no Vale dos Sinos, tomando como exemplo a cidade de São Leopoldo, a terceira mais populosa da região. Nela, o processo de institucionalização começou a ser construído pela municipalidade com a criação do Conselho Municipal de Defesa do Meio Ambiente (CONDEMA), em 20 de julho de 1979. O trabalho do COMDEMA foi respaldado por uma lei municipal que definia o que era um crime contra o meio ambiente e a sua coordenação coube inicialmente ao General Mário Fonseca, personagem citado por alguns entrevistados como importante colaborador na luta pela proteção da natureza em São Leopoldo. Composto por diferentes segmentos da sociedade, o Conselho foi parte de um esforço da municipalidade no sentido de implantar uma política ambiental mais eficiente e mais democrática para o município de São Leopoldo, uma vez que assegurava um espaço alternativo para a participação do movimento ambientalista na administração 
municipal. No final dos anos 80, na mesma época em que a mobilização da UPAN estava crescendo em ritmo acelerado, houve uma reformulação da atuação do município na área ambiental com a criação da atual Secretaria Municipal do Meio Ambiente (SEMMAM). Parte dessa reformulação está presente nas recordaçóes do agrônomo Luís Marcelo Tisian, que associa as mudanças institucionais na política ambiental com o contexto de democratizaçáo que marcou o país no final dos anos 80 e com o trabalho desenvolvido pela UPAN:

(...) muito do que tu estás vendo hoje de criaçóes de secretarias (até essa nossa SEMMAM) veio em função da nossa pressão na época. Vale lembrar que naquela época aconteceu a ECO - 92, a Constituição Federal, depois a Constituição Estadual, as próprias leis orgânicas municipais. Então, nós também ajudamos a pressionar os administradores nesse sentido de criar leis mais protetivas. E eu me sinto muito responsável pela criação de várias secretarias (pela pressão que a gente colocou na época em cima dos administradores). Toda essa questão dos lixôes que, na época, eram nas margens do Rio dos Sinos (...), hoje mudou bastante, a maioria dos lixôes não foram recuperados, mas foram ao menos saneados e abandonados, e foram criadas novas áreas longe da água (alguns têm aterro sanitário, outros, não). Isso foi uma vitória interessante e toda a discussão que vem em cima disso, a questão da reciclagem, (...) a questão da separação do lixo que as próprias prefeituras estáo incentivando e a coleta seletiva, que praticamente tem em todos os municípios.

Eu me sinto bem responsável por isso, uma pequena parcela de responsabilidade, não eu, e sim a UPAN na época (...). Eu acho que foi um salto de qualidade daquela época para cá com certeza, e a UPAN teve uma parcela de participação considerável nessa melhora.

A "participação" na criação de órgãos públicos, assim como a "pressão" para a elaboração e execução de leis, são exemplos de açóes politizadas que nos ensinam como os ambientalistas do Vale dos Sinos expressaram, na prática, o ideal de preservação da natureza. Nesse sentido, o conjunto de entrevistas da pesquisa contém uma série de recordaçóes semelhantes em que o ambientalismo passou a interferir em práticas de órgãos públicos ou em situaçóes que já faziam parte do cotidiano da população. 
A satisfação pelo envolvimento na criação e qualificação de serviços municipais mais capacitados para o atendimento de demandas ambientais é um componente importante na memória de alguns ambientalistas entrevistados. E, junto com esse componente, várias narrativas apresentam um trabalho de inserção das lutas ambientalistas locais em esferas políticas mais amplas, como o governo estadual ou mesmo o governo federal. $\mathrm{O}$ exemplo mais significativo procede das recordaçóes de Arno Kayser a respeito do processo de produção de leis de proteção ao meio ambiente:

(...) nos anos de 87/88, o Brasil estava vivendo um processo de redemocratização cuja culminância institucional foi a Assembleia Nacional Constituinte com o Ulysses Guimarães, o que resultou na atual Constituição Brasileira. No período anterior, entre a eleição do Parlamento, que foi em 86 (se eu não me engano), e a publicaçáo da Constituição, que foi em 88 , houve um grande processo de mobilizaçáo da sociedade brasileira no sentido de criar um capítulo do meio ambiente. A gente tinha o Deputado Fábio Feldmam, de São Paulo, como uma espécie de referência; ele foi eleito com essa bandeira de criar um capítulo do meio ambiente na Constituiçáo Brasileira, e ele conseguiu articular movimentos sociais e entidades ambientais em um grande fórum que atua até hoje, o Fórum Brasileiro de ONGs e Movimentos Ambientais (eu não me recordo agora a sigla dele), que depois começou a trabalhar a organização da ECO - 92 no Brasil, mas, anteriormente, esse pessoal se reuniu no sentido de formatar um capítulo sobre meio ambiente, que é o documento que está lá consagrado pela Constituição e que foi fruto de movimentos ecológicos de mais de mil entidades de todo o país que atuaram até chegar àquele texto que reflete bem o ambiente da época (a questáo das bombas atômicas). E, como consequência disso, vieram as Constituiçôes Estaduais, o movimento ecológico gaúcho também participou dentro desse mesmo esforço, e depois as Leis Orgânicas Municipais; então, nós também aproveitamos toda essa experiência que o Movimento Roessler participou (...), e a gente propôs um capítulo do meio ambiente que é o que está praticamente vigorando até hoje.

Kayser e Tisian não foram os únicos entrevistados que relacionaram a atuação política do movimento ambientalista local com o processo de redemocratização do país vivido nos anos 80. Tibúrcio Marques Neto, um dos 
líderes da juventude luterana de Novo Hamburgo nos anos 80, recordando sua atuação na Terraguar, mencionou a existência de um "idealismo" compartilhado pelos ambientalistas, uma pretensão de poder mudar o mundo a partir do envolvimento da sociedade com a Ecologia. Na sua narrativa, destacou o clima de otimismo gerado pela reabertura democrática e o seu efeito estimulante para a expansão do movimento ambientalista na regiáo.

Todas essas recordaçóes caracterizam o final dos anos 80 como um período de intensa politização do ambientalismo no Vale dos Sinos. Foi nesse período que o jornalista Carlos Aveline projetou-se como líder da UPAN e ocupou cargos destacados no âmbito nacional do movimento ambientalista. Com Aveline na presidência da UPAN, a entidade iniciou a fase das açóes judiciais contra o governo e contra empresas responsáveis por danos ao meio ambiente - possibilidade jurídica criada com a Lei da Ação Civil Pública (Lei n. 7.347 de 1985).

O nome de Carlos Cardoso Aveline está presente na memória de vários ambientalistas entrevistados. Luís Marcelo Tisian, que foi seu colega na UPAN no período de 1986-1992, enfatizou a contribuição da formaçáo jornalística de Aveline para tornar de domínio público informaçóes referentes ao meio ambiente que, muitas vezes, permaneciam guardadas pelo governo ou que não recebiam espaço na imprensa comum. $\mathrm{O}$ ambientalista Márcio Linck associou qualidades pessoais de Aveline como liderança, dedicação, preparo intelectual e capacidade de motivação, ao crescimento do ativismo ambientalista regional. João Ignácio Daudt, professor de Biologia que acompanhou como sócio/militante a transição da Agapan-NL para UPAN (transição ocorrida em 1986, a partir da reformulação do estatuto da associação), ressaltou que as açóes judiciais encaminhadas por Aveline para cobrar do governo medidas de proteção ambiental iniciaram uma nova fase na história da entidade.

Liderada por Carlos Aveline, a UPAN amadureceu o seu ativismo ambientalista com a elaboração de um plano de recuperação do Rio dos Sinos, o qual orientou a expansão dos trabalhos da entidade. Márcio Linck relembrou com detalhes os principais pontos desse plano:

Então se estabeleceram sete pontos de recuperação e preservação do Rio dos Sinos. O primeiro ponto era o tratamento primário das indústrias coureiro-calçadistas (os curtumes); o segundo ponto era o tratamento 
secundário, e aí foi uma luta muito grande com indústrias de curtume nesse período de 85/86 por aí; o terceiro ponto era o tratamento de efluentes de outros ramos industriais, e aí atacamos siderúrgicas, metalurgia, alimentícia, (...) a principal fonte de poluição era a poluição industrial, diferente de hoje. O quarto ponto era o tratamento de esgoto, o esgoto cloacal, e hoje náo está bem resolvido (...). O quinto ponto era a questão do lixo, dos lixóes, porque praticamente todas as cidades do Vale do Rio dos Sinos tinham depósitos de lixo em áreas de banhados, áreas de inundaçáo do rio ou próximo a arroios; então se travou uma briga tremenda (seja com açóes judiciais, seja com pressão e com abaixo-assinado) contra os lixóes. Saindo do quinto ponto, que eram os lixóes, no sexto ponto, foram feitas poucas experiências nesse sentido, era a questão de parar com o desmatamento e reflorestar as margens do Rio dos Sinos. Alguma coisa foi feita pelo movimento ecológico em algumas ações bem pontuais, não houve uma ação do Poder Público, "vamos preservar as margens do Rio dos Sinos”, não houve muito isso. E o sétimo ponto desse programa de recuperação do Rio dos Sinos era formar uma administração da Bacia do Rio dos Sinos, uma espécie de condomínio onde todos os setores envolvidos (empresários, entidades ambientalistas, veículos de comunicação, imprensa, associações de bairro), enfim, estariam unidos e cada um faria a sua parte (...). Essa ideia do sétimo ponto resultou no que hoje é o COMITESINOS.

Em todos os pontos do plano para recuperação do Rio dos Sinos recordados por Linck, podemos perceber interaçóes entre o ambientalismo e a política, desde que se tenha, no entanto, uma concepção ampla e flexível do que é a política e de quais as suas competências. No caso específico da pesquisa realizada com ambientalistas do Vale dos Sinos, as recordaçóes apontam para três tipos distintos de política: (a) a mobilização de segmentos sociais contra a poluição hídrica e contra o alto custo ambiental decorrente da industrialização local; (b) a cobrança da responsabilidade dos órgãos públicos no aperfeiçoamento e no cumprimento da legislação ambiental existente; (c) o uso de recursos culturais diversos - incluindo os trabalhos educativos e a produção textual - em favor da publicidade e do envolvimento comunitário com a preservação ambiental. Na prática, esses três tipos de política se complementavam e reforçavam o potencial de interferência do ambientalismo no comportamento da sociedade civil e nas açóes governamentais. 


\section{Conclusão: pontos para uma necessária reflexão}

O processo de desenvolvimento do ambientalismo é um capítulo novo na história das relaçóes entre o ser humano e o meio ambiente e, apesar da existência de um crescente esforço historiográfico voltado para o estudo das lutas pela preservaçáo da natureza, o conhecimento histórico existente ainda é pouco expressivo diante da relevância social das questôes ambientais contemporâneas, mas, se obsevarmos as contribuiçóes de estudos procedentes de áreas acadêmicas, como a Sociologia Ambiental e as Ciências Políticas, poderemos perceber uma conjuntura favorável ao crescimento da História Ambiental e ao uso da História Oral em trabalhos voltados para a compreensão da formação e do funcionamento do ambientalismo.

Teoricamente, a metodologia da História Oral diferencia-se pela proposta de valorização de fontes orais e pelo envolvimento do pesquisador na produção e transcrição das recordaçôes narradas. Sabemos também que ela possui um limite reduzido de alcance cronológico, uma vez que o exercício da memória é um privilégio dos vivos e, mesmo estes, precisam conviver com esquecimentos e falhas nas suas recordaçóes. No caso específico do ambientalismo, devemos considerar que a segunda metade do século XX corresponde ao período de maior intensificação e de projeção pública das lutas pela preservação da natureza e, consequentemente, o limite cronológico existente para a prática da História Oral não prejudica o trabalho historiográfico de registrar, preservar, analisar e socializar as recordaçóes existentes na memória das pessoas que participaram das lutas pela preservação da natureza.

Igualmente importante na metodologia da História Oral é a viabilidade de explorarmos o trabalho de ressignificação do passado que ocorre no momento das entrevistas, reconhecendo nele o que Alessandro Portelli denominou de "experiência dialógica." Segundo Porteli, a História Oral ganha forma na interação entre o gênero da narrativa e o discurso científico do historiador, e

tende a representar a realidade não tanto como um tabuleiro em que todos os quadrados são iguais, mas como um mosaico ou colcha de retalhos, em que os pedaços são diferentes, porém formam um todo coerente depois de reunidos - a menos que as diferenças entre elas sejam tão irreconciliáveis que talvez cheguem a rasgar todo o tecido. (Portelli, 1997, p. 16). 
Na metáfora da "colcha de retalhos", encontramos uma advertência para o risco de confundirmos a História Oral com os fragmentos de memória que ela seleciona, organiza e interpreta; para evitar esse risco, devemos reconhecer que o uso do material produzido por meio das entrevistas representa, sempre, uma interferência do pesquisador na memória que está sendo estudada.

Rica pela própria dinâmica do método, a "experiência dialógica" que acompanha a prática da História Oral excede a elaboração de textos e mantém em aberto a perspectiva de socialização de saberes e de novos diálogos mediados, em parte, pela fonte oral e, em parte, pela análise historiográfica. Na sua etapa inicial, a História Oral é o produto de um encontro do pesquisador com as recordaçóes dos entrevistados e, na sua etapa final, ela é um trabalho de interpretação histórica que, apesar das particularidades metodológicas, também está sujeito à apreciação crítica e a reformulaçóes.

No atual contexto historiográfico, a antiga discussão sobre a credibilidade das fontes orais já está superada e existe na comunidade de historiadores a percepção de que o passado recordado na prática da História Oral não está isento de equívocos ou de esquecimentos e omissóes, uma vez que tal passado recebe a crítica do seu próprio narrador e interage com as interferências do pesquisador na memória do entrevistado. Entretanto, isso não diminui o valor da oralidade como fonte documental, desde que se reconheça que a ressignificação do passado é uma consequência inevitável da História Oral e, ao mesmo tempo, um atrativo para o uso dessa metodologia de pesquisa.

A pesquisa de História Oral, realizada com ambientalistas do Vale do Rio dos Sinos, não contemplou todos os temas possíveis, e o trabalho iniciado pode ser ampliado com a inclusão de novos entrevistados e com a própria releitura das transcriçôes. Nesse aspecto, a História Oral apresenta aberturas para acréscimos, revisóes e reinterpretaçóes e, no decorrer do seu desenvolvimento, pode incorporar fatos novos, como, por exemplo, a grande mortandade de peixes ocorrida no Rio dos Sinos em 2006. Certamente, essa catástrofe ambiental pode ser estudada a partir de dados da imprensa ou através dos documentos do governo, mas, quando condicionamos a interpretação do passado ao conteúdo dessas fontes, perdemos a possibilidade de explorar as particularidades da História Oral, dentre as quais podemos destacar o trabalho de seleção e organização das recordaçóes, a existência dos esquecimentos, a relação do fato específico com o conjunto de memórias do entrevistado, a significação da narrativa e as interferências (implícitas 
ou explícitas) do pesquisador no fluxo das memórias e na composição das narrativas.

\title{
Fontes orais
}

\author{
Arno Kayser \\ Augusto Carneiro da Cunha \\ Ernest Sarlet \\ João Ignácio Daudt \\ Kurt Schmeling \\ Luís Marcelo Tisian \\ Maria Olisa \\ Márcio Linck \\ Tibúrcio Marques Neto \\ Werner Ziegler
}

\section{Referências}

ALEXANDRE, Agripa Faria. A perda da radicalidade do movimento ambientalista brasileiro: uma contribuiçâa à crítica do movimento. Blumenau: Universidade Regional de Blumenau, 2000 .

CARVALHO, Isabel Cristina de Moura. A invenção ecológica: narrativas e trajetórias da educação ambiental no Brasil. narrativas e trajetórias da educação ambiental no Brasil. 2. ed. Porto Alegre: UFRGS, 2002.

GRÜN, Mauro. Ética e Educação Ambiental: a conexão necessária. São Paulo: Papirus, 1996.

MERGEL, Thomas. Algumas consideraçôes a favor de uma História Cultural da Política. História Unisinos. São Leopoldo, v. 7, n. 8, p.11-56, jul./dez. 2003.

PEREIRA, Elenita Malta. Um protetor da natureza: trajetória e memória de Henrique Luiz Roessler. Dissertaçáo de História. Porto Alegre, UFRGS, 2011.

PINTO, Júlio Pimentel. Os muitos tempos da memória. Projeto História, São Paulo, n. 17, p. 203-213, nov. 1998.

PRADO, Daniel P. A figueira e o machado: uma história das raizes do ambientalismo no Sul do Brasil e a crítica ambiental de Henrique Roessler. Rio Grande: FURG, 2011. 
PORTELLI, Alessandro. Tentando apreender um pouquinho. Algumas reflexôes sobre a ética na História Oral. Projeto História. São Paulo, n. 15, p. 13-33, abr. 1997.

. História Oral como Gênero. Projeto História. São Paulo, n. 22, p. 9-35, jun.

2001.

RÜCKERT, Fabiano Quadros. História e Memória do Ambientalismo no Vale dos Sinos. Dissertação de História. Unisinos, São Leopoldo, 2007.

RUSCHEINSKY, Aloísio. A pesquisa em história oral e a produção do conhecimento em educação ambiental. In: SATO, Michele; CARVALHO, Isabel Cristina de Moura. Educação Ambiental: pesquisa e desafios. Porto Alegre: Artmed, 2005, p. 135 - 149.

Resumo: Partindo da premissa de que a memória é uma construção social que pode comportar diferentes significaçóes do passado e considerando a História Oral como potencializadora da produção e socialização de memórias, o conteúdo deste artigo pretende abordar as relaçôes entre os ambientalistas e o Poder Público no Vale do Rio dos Sinos - estado do Rio Grande do Sul. O texto relata, a partir das recordações dos entrevistados, experiências de mobilização dos ambientalistas voltadas para a ampliação e qualificação dos serviços públicos na área ambiental. A primeira parte do artigo contempla o trabalho dos ambientalistas promovendo a Educação Ambiental como reação diante da degradação da natureza na região; a segunda parte é composta por fragmentos de memória referentes ao papel do Poder Público na preservação ambiental, mediante a criação de leis ou de serviços específicos.

Palavras-chave: História Oral, memória, ambientalismo.

Crossroads: the Environmental and Public Power River Valley of the Bells - RS

\begin{abstract}
Assuming that memory is a social construction that can hold different meanings of the past and considering the Oral History as a potentiator oof production and socialization of memory, the contents of this article aims to anddress the relationship between environmentalists and the Government of the River Valley bell - State of Rio Grande do Sul the text highlights the memories of respondents, experience of mobilizing environmentalists focused on expansion and qualification of public services in the environmental area. The first part of the paper considers the work of environmentalists promoting environmental education as a reaction to the degradation of nature in the region, the second part is composed of fragments of memory concerning the role of government in the environmental preservation by creating laws and services specifics.
\end{abstract}

Key words: oral history, memory, environmentalism.

Recebido em: 02/08/2012

Aprovado em: 02/09/2012 